\title{
К 200-ЛЕТИЮ ВЕЛИКОГО ГЕОГРАФИЧЕСКОГО ОТКРЫТИЯ
}

\author{
DOI: $10.31857 /$ S258755662001015X
}

В январе 2020 г. исполняется ровно 200 лет величайшего со времен Магеллана географического открытия - достижения Антарктического материка. Последний, шестой континент Земли стал известен по меркам всемирной истории совсем недавно. В январе 1820 г. Русская кругосветная экспедиция под командованием Ф.Ф. Беллинсгаузена и М.П. Лазарева впервые увидела его берег.

В поисках Южного материка русская экспедиция прошла южнее полярного круга, и 28 января (по новому стилю) 1820 г., когда корабли находились под $69^{\circ} 21^{\prime}$ ю.ш. и $2^{\circ} 15^{\prime}$ в.Д., моряки заметили большие бугристые ледяные поля, отличавшиеся от всех виденных до сих пор. В дневниках в эти дни появились характерные записи:

"5 февраля при сильном ветре тишина моря была необыкновенная. Множество полярных птиц и снежных петрелей вьется над шлюпом. Это значит, что около нас должен быть берег или неподвижные льды... мы устремились сквозь льды к ледяному берегу” (Новосильский, 1853). Позднейшие исследования показали, что шлюпы “Восток” и "Мирный” находились в это время не далее чем в 20-25 км от берега Антарктиды.

Экспедиция Ф.Ф. Беллинсгаузена и М.П. Лазарева дала первые сведения о льдах и снежном покрове Антарктики. На основании изучения свойств и строения неподвижных и плавающих льдов Ф.Ф. Беллинсгаузен составил первое описание и классификацию льдов в антарктических морях.

Это было главное географическое открытие после заявления полувековой давности, сделанного Джеймсом Куком, о том, что люди вряд ли когдалибо пробьются на юг и увидят, что скрывает Южный океан. Но Русская экспедиция в поисках Южно-полярного материка достигла антарктического берега. Вскоре его увидели и британские, и североамериканские моряки, но это были китобои, тогда как Россия снарядила в южно-полярные воды хорошо оснащенную научную экспедицию, которая провела обширные исследования, опубликованные впоследствии в трудах экспедиции.

В период Первой экспедиции в Антарктиде было открыто много географических объектов, которые получили русские имена. Позднее в период Второй экспедиции в 1821 г. на карте побережья материка и в омывающих его водах появились Земля Александра I, острова - Петра I, Бородино, Ватерлоо, Смоленск, Малый Ярославец, Шишкова, Новосильского и др. Жаль, что многие из них позднее оказались переименованными иностранными исследователями. Но в год юбилея мы должны помнить и об этих приоритетах в истории изучения $\mathrm{AH}-$ тарктиды.

Начиная с открытия Антарктиды русской экспедицией, интерес к Антарктическому материку не ослабевал. В дальнейшем экспедиции Уэдделла (1822-1823 гг.), Дюмон-д’Юрвиля (1838-1840 гг.), Уилкса (1840 г.), Росса (1841 г.), Джерлаха (1898 г.), Норденшельда и Ларсена (1902 г.), Дригальского (1902 г.), Скотта (1902 и 1912 гг.), Ширазе (1911 г.), Моусона (1912 г.), Шеклтона (1908 г.), Фильхнера (1912 г.), Амундсена (1912 г.), Бёрда (1928-1941 гг.), Уилкинса (1928 г.), Элсуэрта (1933-1939 гг.) получили важные сведения о прибрежных районах материка. В 1930-х годах, в связи с подготовкой ко второму Международному полярному году в Советском Союзе появились идеи об организации советской полярной станции в Антарктиде, но в те годы для страны было гораздо важнее освоение арктических территорий.

Однако после завершения второй мировой войны во многих странах вновь возник интерес к Антарктиде, и находящийся тогда на подъеме и имевший непререкаемый авторитет Советский Союз вновь обратился к этой территории. В согласии с Соединенными Штатами было принято решение “заморозить” претензии семи стран (Великобритании, Франции, Норвегии, Австралии, Новой Зеландии, Чили и Аргентины), на владения в Антарктиде и превратить эту часть земного шара в регион не противостояния государств, а их сотрудничества на благо науки и процветания людей.

В 1950-х годах возникла идея проведения Международного геофизического года и создания сети научных станций по всему миру, включая Антарктику. Советский Союз принял в этом активное участие, и уже вскоре на антарктическом Берегу Правды была основана первая советская станция "Мирный”, а перед Советской Антарктической экспедицией была поставлена задача создания еще двух внутриконтинентальных станций - “Восток” в районе Южного геомагнитного полюса и "Советская" в районе Полюса относительной недоступности Восточной Антарктиды.

Но все задуманное выполнить оказалось очень не просто - задача сильно осложнялась из-за отсутствия необходимого опыта. Тогдашние тягачи имели низкую посадку и недостаточную ширину гусениц, что приводило к очень глубокой колее в рыхлом снеге 
Центральной Антарктиды, и скорости движения первых санно-тракторных поездов внутри континента были гораздо меньше предполагавшихся.

В феврале 1957 г. санно-тракторный поезд с большими трудностями дошел до Комсомольской, и здесь, на высоте 3540 м над ур. м., в течение двух лет наши полярники проводили постоянные наблюдения. 28 февраля 1957 г. из Мирного отправился главный санно-тракторный поезд для организации станции Восток, но он вынужден был остановиться на высоте 3250 м, где была организована временная станция Восток-1. Лишь с приходом нового лета станция была “передвинута" на запланированное ранее место и открыта 16 декабря 1957 г. на высоте 3490 м.

С тех пор на этой станции непрерывно проводится широкий комплекс наблюдений, а 5 февраля 2012 г. завершено на глубине 3769.3 м многолетнее бурение скважины, проникшей в крупнейшее в Антарктиде (примерно в треть Байкала) подледное озеро, существование которого еще в 1960-х годах было предсказано российским географом и гляциологом, сотрудником Институга географии РАН И.А. Зотиковым на основе теплофизических расчетов.

$\mathrm{C}$ тех пор прошло более полувека, и Антарктида уже давно не “неведомая земля". С началом массовых космических съемок поверхности нашей планеты стали обычными и дистанционные наблюдения шестого континента. Они принесли принципиально новые сведения и о поверхностных процессах на Антарктическом ледниковом покрове, и позволили подойти к очень важному и сложному вопросу о его современном состоянии. Эта проблема приобретает сейчас, в эпоху глобального потепления на земном шаре особую актуальность, так как в случае отрицательного баланса массы ледникового покрова Антарктиды мы можем ожидать ускоренный подъем уровня Мирового океана, что грозит затоплением многим прибрежным территориям.

Современная эпоха глобального потепления на земном шаре, конечно, отражается на общем состоянии Антарктического ледникового покрова и балансе его массы. Потепление ведет к увеличению содержания водяного пара в воздушных массах, вызывает интенсификацию атмосферной циркуляции и рост снегонакопления на поверхности ледникового щита. Вместе с тем потепление океанических вод и некоторое увеличение температуры льда приводят к росту скоростей течения льда и большему расходу льда на береговой линии материка. Изучение и расчеты этих процессов и их соотношения не просты и до сих пор не получили законченного решения.

Обширные исследования в южно-полярной области Земли, проведенные еще в период Международного геофизического года (1957-1958 гг.), привели к предположению о современном росте массы льда в Восточной Антарктиде, что вызывало естественное удовлетворение, так как очевидно, что подобный процесс замедляет повышение уровня Мирового океана, вызываемое усиленным таянием льдов в умеренных широтах. Однако в последние годы, наоборот, происходит усиленное таяние льда в Западной Антарктиде и на Антарктическом полуострове, что нивелирует повышенный приход массы льда в Восточной Антарктиде. Поэтому в целом в современную эпоху глобального потепления масса льда в Антарктиде в целом уменьшается, но совсем немного, и в результате уровень Мирового океана повышается за счет стаивания ледникового покрова Антарктиды не более чем на 0.1 мм в год.

Таким образом, по сравнению с масштабами Антарктического ледникового покрова его вклад в повышение уровня моря незначителен. Главная причина этого заключается в том, что в Восточной Антарктиде накопление массы со значительной долей вероятности преобладает над расходом льда.

Впрочем, каковы бы ни были антропогенные изменения климата, они накладываются на его естественные вариации, масштаб которых все еще сильно превосходит влияния, обусловленные эмиссией парниковых газов. Детальные исследования керна из глубоких скважин, пробуренных на ледниковых покровах Антарктиды (прежде всего на российской станции Восток) позволяют сделать важные заключения.

Во-первых, предсказать последствия роста концентрации парниковых газов в атмосфере (так называемое глобальное потепление вследствие парникового эффекта) невозможно без понимания естественной изменчивости природных процессов, на которые накладывается антропогенное влияние.

Во-вторых, концентрация парниковых газов и глобальная температура в прошлом изменялись параллельно, как это следует из анализа ледяных кернов, но содержание газов резко возросло за последние 100 лет, тогда как изменения температуры не выходят за рамки ее естественных флуктуаций.

В-третьих, ряд данных свидетельствует о том, что климат в прошлом менялся гораздо сильнее, чем в период регулярных инструментальных наблюдений, т.е. за последние 150 лет. Если события такого масштаба повторятся в будущем, их социально-экономические последствия могут быть настолько серьезны, что к ним не смогут адаптироваться социальные и экономические системы.

В-четвертых, данные из глубокой ледниковой скважины на станции Восток свидетельствуют, что голоцен, продолжающийся уже около 11 тыс. лет, оказывается намного длиннее предыдущих четырех межледниковых периодов и, по многим признакам, в ближайшем геологическом будущем сменится новой ледниковой эпохой.

В наше время Антарктический материк с его огромными природными богатствами привлекает пристальное внимание и ученых, и политиков, но его спокойствие и природные богатства надежно защищены от любых посягательств Антарктическим договором. Антарктида по-прежнему - область мира и согласованных научных исследований.

B.М. Котляков 